\title{
Sexual seasonal growth variation and reproduction biology of the rock pool prawn, Palaemon elegans (Decapoda: Palaemonidae) in the southern Black Sea
}

\author{
SABRI BILGIN ${ }^{1}$, OZCAN OZEN $^{1}$ and OSMAN SAMSUN ${ }^{2}$ \\ ${ }^{1}$ Canakkale Onsekiz Mart University, Faculty of Fisheries, Canakkale 17100, Turkey. E-mail: oozen@ comu.edu.tr \\ ${ }^{1}$ Sinop Universitesi, Faculty of Fisheries, Sinop 5700, Turkey.
}

\begin{abstract}
SUMMARY: The seasonal growth pattern and reproductive biology of the rock pool prawn, Palaemon elegans, were studied in the southern Black Sea between February 2002 and January 2004. The seasonal von Bertalanffy growth parameters, computed from monthly length frequency distributions, were estimated as $\mathrm{L}_{\infty}=47.8 \mathrm{~mm}$ total length (TL), $\mathrm{K}=1.115$ year $^{-1}$ for females and as $L_{\infty}=41.1 \mathrm{~mm} \mathrm{TL}, K=1.654$ year $^{-1}$ for males. The seasonal oscillation in growth rate for females $(\mathrm{C}$ $=0.904)$ was larger than it was for males $(C=0.586)$. The slowest period of growth corresponded to June in females and February in males. The size at sexual maturity for females $\left(\mathrm{TL}_{50}\right)$ was estimated as $33.8 \mathrm{~mm}$ TL. Ovigerous females were recorded from March to August and juveniles appeared in the benthic population in August. The ovarian development of the rock pool prawn was most probably initiated by photoperiod, whereas embryo development was accelerated with increasing water temperatures.
\end{abstract}

Keywords: rock pool prawn, Palaemon elegans, seasonal growth, reproduction cycle, maturity size, Black Sea.

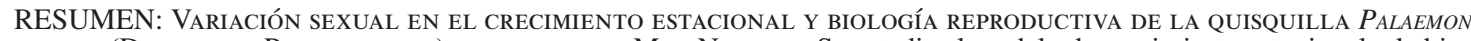
elegans (DeCaPoda: Palemonidae) En el Sur del Mar Negro. - Se estudia el modelo de crecimiento estacional y la biología reproductiva de la quisquilla Paleamon elegans en la parte sur del Mar Negro, entre febrero de 2002 y enero de 2004. Los parámetros de crecimiento estacional por meses, calculados mediante el modelo de von Bertalanffy, se estimaron en $\mathrm{L}_{\infty}=47.8 \mathrm{~mm}$ de longitud total (TL), $\mathrm{K}=1.115 \mathrm{año}^{-1}$ para hembras y en $\mathrm{L}_{\infty}=41.1 \mathrm{~mm} \mathrm{TL}, \mathrm{K}=1.654$ año ${ }^{-1}$ para machos. La oscilación estacional de crecimiento para hembras $(\mathrm{C}=0.904)$ fue mayor que para machos $(\mathrm{C}=0.586)$, y el periodo de crecimiento lento para hembras correspondió al mes de junio y el de machos en febrero. La talla de primera madurez sexual $\left(\mathrm{TL}_{50}\right)$ de las hembras se estimó en $33.8 \mathrm{~mm}$. Las hembras ovadas se observaron entre marzo y agosto y la mayoría de juveniles fueron reclutados en el bentos en agosto. El desarrollo ovárico parece ser iniciado por el fotoperíodo, mientras que el desarrollo embrionario se aceleró con el incremento de la temperatura del agua.

Palabras clave: quisquilla, Palaemon elegans, crecimiento estacional, ciclo reproductor, talla de madurez, Mar Negro.

\section{INTRODUCTION}

The rock pool prawn, Palaemon elegans Rathke, 1837 , is distributed along the North Sea, Baltic Sea, eastern Atlantic, Mediterranean, and Black Sea (Udekem d'Acoz, 1999; Janas et al., 2004). It inhabits bottoms covered with Zostera marina meadows, bare sandy bottoms, in moving waters and in rock pools (Berglund, 1980). It shows sexual dimorphism and females grow up to $50 \mathrm{~mm}$, whereas males reach a size of about $45 \mathrm{~mm}$ (Forster, 1951; Berglund, 1981; Lapińska and Szaniawska, 2006).

Research into P. elegans includes genetics (Berglund and Lagercrantz, 1983), habitat preferences (Berglund, 1980, 1982; Schaffmeister et al., 2006), behaviour (Morris and Taylor, 1985; Evans et al., 
2007; Janas and Spicer, 2008), growth (Forster, 1951; Berglund, 1981) and physiology (Morris and Taylor, 1985; Janas and Spicer, 2008). In addition, the reproduction biology of $P$. elegans has been investigated in terms of egg characteristics (Berglund, 1984), fecundity (Sanz, 1987; Bilgin and Samsun, 2006), and reproductive success (Berglund, 1985).

Age determination of crustaceans is difficult because the exoskeletons are lost during each moult and therefore no persistent skeletal structures are retained to provide a record of age and growth (Hartnoll, 2001). Analyses of length frequency data (LFDA) can be used for estimating age classes and growth parameters (Pauly and David, 1981), and can also be applied to calculate growth of decapod crustaceans (Tuck et al., 1997; Oh et al., 1999). An additional challenge for estimating growth of decapod crustaceans arises due to the seasonal growth pattern, and a modified von Bertalanffy growth model has been developed to incorporate this (Hoenig and Hanumara, 1982).

A seasonal growth pattern has been reported for different Palaemon species, such as $P$. xiphias (Guerao et al., 1994), P. gravieri (Kim, 2005), $P$. adspersus (Berglund, 1981; Baden and Pihl, 1984), and P. elegans (Berglund, 1981). However, there is no information on the seasonal growth rate of $P$. elegans. In addition, knowledge on the reproductive biology of the rock pool prawn is very limited in the literature. The aim of this study was to estimate seasonal von Bertalanffy growth parameters for each sex using length frequency data and investigate the reproductive biology with respect to monthly proportions of ovigerous females of $P$. elegans.

\section{MATERIALS AND METHODS}

Monthly samplings were conducted between February 2002 and January 2004 in the Sinop Peninsula, Black Sea (Fig. 1). Individuals were captured between 1 and $30 \mathrm{~m}$ depth with a beam trawl of $3 \mathrm{~m}$ length, $30 \mathrm{~cm}$ width and $10 \mathrm{~mm}$ codend mesh size. A total of 119 hauls was conducted during the study period. Mean towing speed was about 2 knots. Sampling duration ranged between 10 and 30 minutes per haul. The bottom structure included seagrass beds, bare sandy bottoms, and muddy habitats. Surface water temperatures and salinities were obtained from a study that was carried out simultaneously in the same area. The water temperature ranged be-

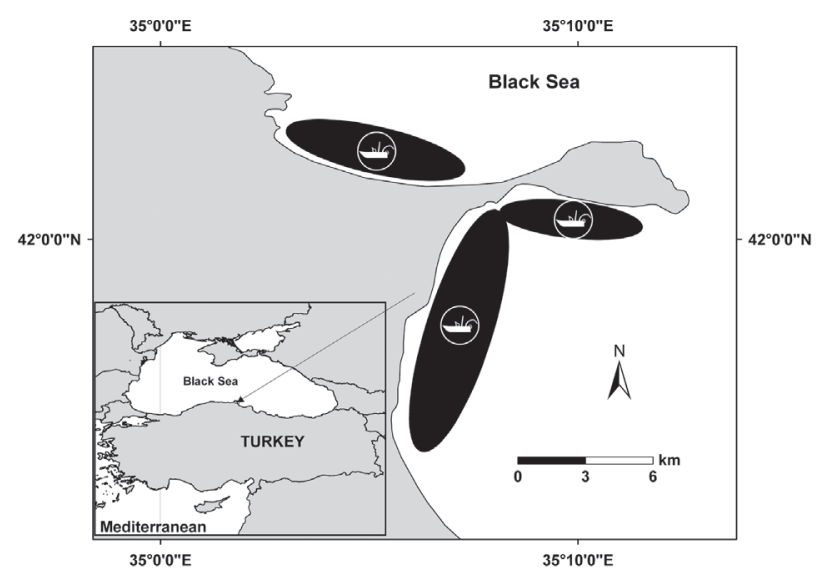

FIG. 1. - Sampling sites (shaded areas) in the Sinop Peninsula, Black Sea.

tween $7^{\circ} \mathrm{C}$ and $26^{\circ} \mathrm{C}$ and the salinity ranged between 17 and 18 in the sampling area during the study.

The presence (males) or absence (females) of an appendix masculina on the second pleopod was the criterion for sex determination (Berglund, 1981). Individuals of $22 \mathrm{~mm}$ TL and smaller were considered to be juveniles. In addition, some small specimens ( $\leq 26 \mathrm{~mm}$ TL) that could not be sexed were regarded as juvenile (see Fig. 2). The total length (TL) of each shrimp was measured from the tip of the rostrum to the posterior end of the telson (excluding spines) and the carapace length was measured from the posterior margin of the orbit to the mid-dorsal posterior edge of the carapace with an accuracy of $1 \mathrm{~mm}$. Specimens were weighed (wet weight) on a balance with a sensitivity of $0.001 \mathrm{~g}$.

The weight-length relationship was estimated using log transformed weight and length data as:

$$
\log (\mathrm{W})=a+b \times \log (\mathrm{TL})
$$

where $\mathrm{W}$ is the body weight $(\mathrm{g}), \mathrm{TL}$ is the total length $(\mathrm{mm}), a$ is the intercept, and $b$ is the slope of the regression line. The comparisons between the slopes of the log-transformed regression lines were carried out using analysis of covariance (ANCOVA).

The von Bertalanffy growth (VBG) equation $\mathrm{L}_{t}$ $=\mathrm{L}_{\infty}\left[1-\mathrm{e}^{-\mathrm{K}(\mathrm{t}-\mathrm{to})}\right]$ predicts length as a function of age and is used when growth has a non-seasonal pattern. Seasonal growth was described using the Hoenig and Hanumara (1982) version of the VBG equation:

$$
\left.L_{t}=L_{\circ}\left[1-e^{\left[-K\left(t-t_{o}\right)+\left(C \frac{K}{2 \neq}\right) \sin 2 \neq\left(t-t_{S}\right)-\left(c \frac{K}{2 \neq}\right) \sin 2 \neq\left(t_{o}-t_{S}\right)\right.}\right]\right]
$$

where, $L_{t}$ is length at age $t, L_{\infty}$ is the asymptotic length to which the shrimps grow, $\mathrm{K}$ is the growth- 
rate parameter, $\mathrm{t}_{0}$ is the nominal age at which the length is zero, $C$ is the relative amplitude $(0 \leq \mathrm{C} \leq 1)$ of the seasonal oscillations, $\mathrm{t}_{\mathrm{S}}$ is the phase of the seasonal oscillations $\left(-0.5 \leq \mathrm{t}_{\mathrm{s}} \leq 0.5\right)$ that denote the time of year corresponding to the start of the convex segment of sinusoidal oscillation.

The time of the year when the growth rate is slowest, known as the winter point (WP), was calculated as:

$$
\mathrm{WP}=\mathrm{t}_{\mathrm{S}}+0.5 .
$$

Seasonal VBG curves were fitted to the length distributions after first indicating a range of values of $\mathrm{L}_{\infty}$ and $\mathrm{K}$ and reducing the range iteratively to maximize the goodness of fit $(\mathrm{Rn})$ of the curves to the data. Rn was calculated as:

$$
\mathrm{Rn}=10^{\mathrm{ESP} / \mathrm{ASP} / 10}
$$

where ASP is the available sum of peaks, computed by adding the best values of the available peaks, and ESP is the explained sum of peaks, computed by summing all the peaks and troughs hit by the VBG curve. Analyses of the length data were fitted to length frequency distributions grouped into $2 \mathrm{~mm}$ total length size classes using the ELEFAN procedure in the PC-based computer package Version 5.0 of Length Frequency Distribution Analysis (LFDA; Kirkwood et al., 2001).

Growth performances were compared using the growth performance index $\left(\Phi^{\prime}\right)$, which is preferred to using $\mathrm{L}_{\infty}$ and $\mathrm{K}$ individually (Pauly and Munro, 1984), and was computed as:

$$
\Phi^{\prime}=\log (\mathrm{K})+2 \log \left(\mathrm{L}_{\infty}\right) .
$$

Maximum life span for females and males was calculated using the empirical equation proposed by Taylor (1958) as:

$$
A_{95}=t_{0}+\frac{2.996}{K}
$$

where $\mathrm{A}_{95}$ is the life span to attain $95 \%$ of $\mathrm{L}_{\infty}$, calculated from the VBG equation.

For each female, the maturity of the ovary was determined within five categories based on morphological characteristics of the ovaries (Guerao and Ribera, 1995): 1. Immature: ovary thin and translucent; 2. Developing: ovary light green and opaque, and occupies one-fourth of the cephalothorax volume; 3 .
Early mature: ovary occupies one-half of the cephalothorax volume; 4 . Nearly mature: ovary occupies three-quarters of the cephalothorax volume; 5. Ripe: ovary occupies almost all of the cephalothorax, i.e. the pre-spawning stage.

Embryonic development (egg stages) was divided into three stages (Guerao and Ribera, 1995): Stage 1: Vitellus fills more than one-half of the egg volume, non-eyed eggs; Stage 2: Vitellus occupies no more than one-quarter of the egg volume, non-eyed eggs; Stage 3: Eyed eggs. Vitellus occupies less than onequarter of the egg volume, and decreases progressively until hatching.

Size at sexual maturity was determined for females by calculating the proportion of mature females in $2 \mathrm{~mm}$ size classes in the breeding period. Ovigerous females and individuals that passed Stage 3 in the ovarian development stage were considered as mature. The proportion of mature females according to size was fitted to the logistic equation:

$$
\mathrm{P}=\frac{1}{1+e^{a+b \mathrm{TL}}},
$$

where $\mathrm{P}$ is the proportion of mature females, $a$ and $b$ are the coefficients of the equation, and TL is the total length. Size at sexual maturity $\left(\mathrm{TL}_{50}\right)$, corresponding to $50 \%$ of sexually mature females, was calculated from $-(a / b)$. Pseudo- $\mathrm{R}^{2}$ was calculated from the corrected total sum of squares (SS) for the nonlinear regression line as Pseudo- $\mathrm{R}^{2}=1$ - SS(Residual)/SS(Total Corrected $_{\text {) }}$.

Size frequency distribution differences between females and males were tested using the KolmogorovSmirnov two-sample test. Mean total length differences between males and females were tested using the Mann-Whitney U-test. Statistical analyses were considered significant when $P<0.05$.

\section{RESULTS}

A total of 2825 rock pool prawns (1975 females, 850 males, 43 juveniles) were sampled between February 2002 and January 2004. The total lengths of females ranged between 23 and $56 \mathrm{~mm}$ (mean 38.44 $\pm 0.11 \mathrm{~mm})$ and the total lengths of males ranged between 21 and $55 \mathrm{~mm}$ (mean $31.98 \pm 0.16 \mathrm{~mm}$ ) (Fig. 2). Size frequency distributions were significantly different (Kolmogorov-Smirnov two-sample test; $\mathrm{d}=0.566, P<0.001)$ between females and males. The mean total length of females was significantly 


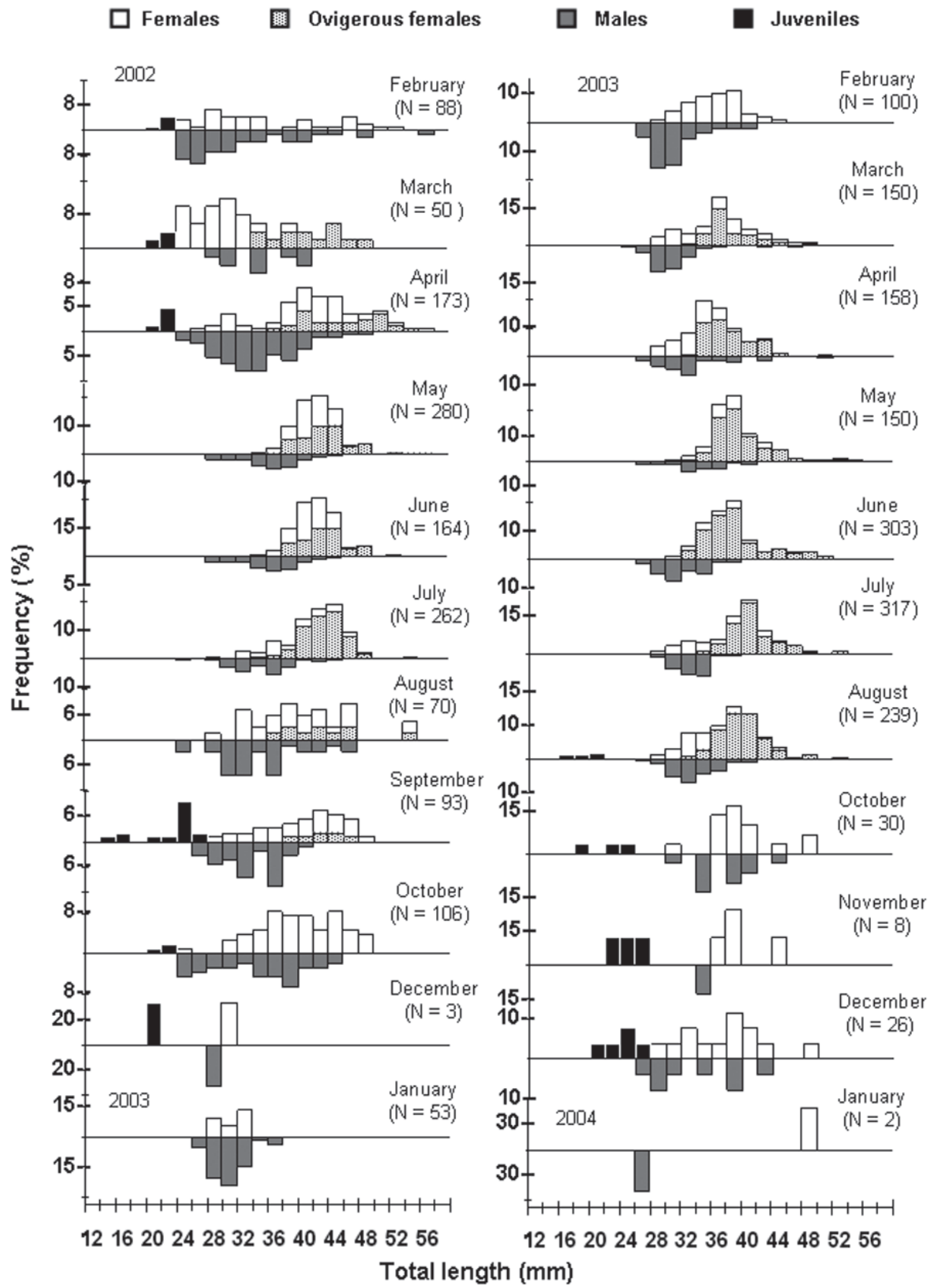

FIG. 2. - Monthly length ( $2 \mathrm{~mm}$ size classes) frequency distributions (in percentages) of females, ovigerous females, males, and juveniles of Palaemon elegans between February 2002 and January 2004. 
(U-test: 2.672E05, $\mathrm{df}=1, P<0.001$ ) greater than the mean total length of males.

The slope of the weight-length relationship was significantly (ANCOVA; $P<0.0001$ ) different between sexes. Therefore, this relationship was investigated separately for each sex. The relationship for males was:

$\log (\mathrm{W})=-4.508+2.851 \log (\mathrm{TL})\left(\mathrm{R}^{2}=0.893, \mathrm{~N}=784\right)$

and for females it was:

$\log (\mathrm{W})=-4.627+3.070 \log (\mathrm{TL})\left(\mathrm{R}^{2}=0.875, \mathrm{~N}=1945\right)$.

The slopes of the regression lines for males and females were significantly different from the isometric growth curve slope of 3 (ANCOVA, $P<0.001$ ).

The comparison of the length-weight relationship between ovigerous and non-ovigerous females revealed that the relationship was significantly different $(P<0.001)$ between these two groups. The relationships were

$\log (\mathrm{W})=-3.770+2.496 \log (\mathrm{TL})\left(\mathrm{R}^{2}=0.818, \mathrm{~N}=1167\right)$

for ovigerous females and

$\log (\mathrm{W})=-4.666+3.023 \log (\mathrm{TL})\left(\mathrm{R}^{2}=0.921, \mathrm{~N}=778\right)$

for non-ovigerous females.

Total length - carapace length (CL) relationships were significantly different between sexes (ANCOVA, $P=0.03)$. The relationship between total length and carapace length for males was:

$$
\mathrm{TL}=0.01332+0.09801 \mathrm{CL}\left(\mathrm{R}^{2}=0.9885, \mathrm{~N}=784\right) .
$$

The total length-carapace length relationship was not significantly different (ANCOVA, $P>0.05$ ) between ovigerous and non-ovigerous females.

The total length - carapace length relationship for females was:

$\mathrm{TL}=-0.00867+0.09897 \mathrm{CL}\left(\mathrm{R}^{2}=0.9902, \mathrm{~N}=1948\right)$

The seasonal and non-seasonal von Bertalanffy growth parameters obtained from the LFDA for each sex are summarized in Table 1. The seasonal LFDA analyses showed that females have higher $\mathrm{L}_{\infty}(47.8$ $\mathrm{mm} \mathrm{TL}$ ) than males (41.1 $\mathrm{mm} \mathrm{TL})$, whereas the growth coefficient value was higher in males (Fig.
TABLE 1. - Seasonal and non-seasonal von Bertalanffy growth parameters estimated from the length frequency distribution analysis for Palaemon elegans males and females. $\mathrm{L}_{\infty}$, asymptotic total length $(\mathrm{mm}) ; \mathrm{K}$, growth coefficient (year-1); to, age at zero length; $\mathrm{WP}$, winter point; $\mathrm{C}$, amplitude of growth oscillation; $\mathrm{Rn}$, goodness of fit index; $\Phi^{\prime}$, growth performance index.

\begin{tabular}{|c|c|c|c|c|}
\hline \multirow[t]{2}{*}{ Parameters } & \multicolumn{2}{|c|}{ Seasonal } & \multicolumn{2}{|c|}{ Non-Seasonal } \\
\hline & Male & Female & Male & Female \\
\hline $\mathrm{L}_{\infty}(\mathrm{mm})$ & 41.083 & 47.768 & 42.282 & 47.878 \\
\hline$K^{\infty}\left(\right.$ year $\left.^{-1}\right)$ & 1.654 & 1.115 & 1.391 & 1.214 \\
\hline$t_{0}$ (year) & -0.600 & -0.990 & -0.800 & -0.980 \\
\hline $\mathrm{WP}$ & 0.172 & 0.548 & - & - \\
\hline $\mathrm{C}$ & 0.586 & 0.904 & - & - \\
\hline$\Phi^{\prime}$ & 3.446 & 3.406 & 3.396 & 3.444 \\
\hline $\mathrm{Rn}$ & 0.458 & 0.352 & 0.419 & 0.314 \\
\hline
\end{tabular}

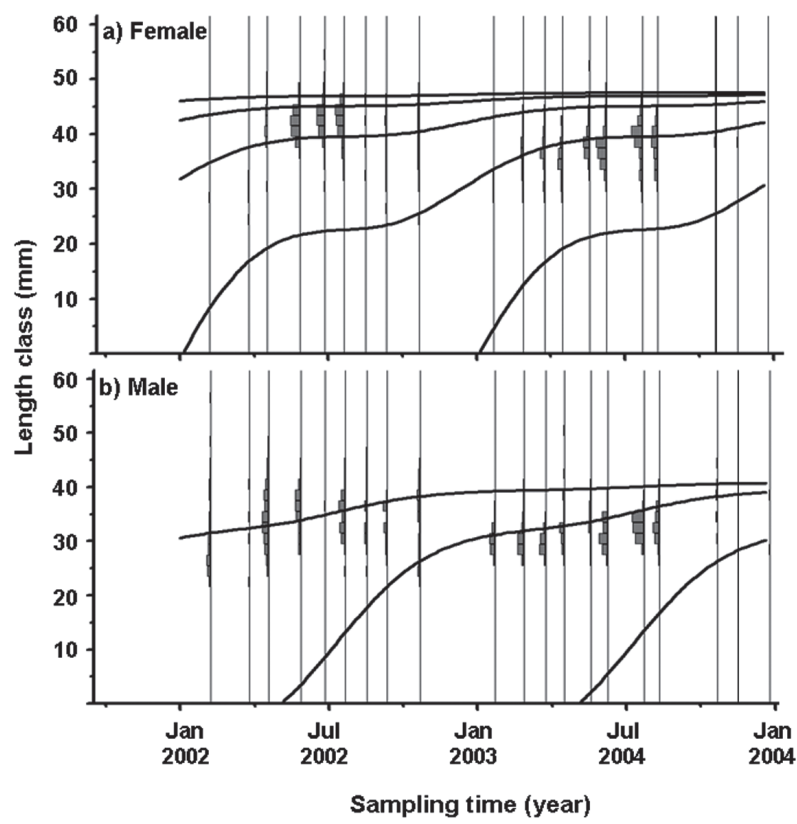

FIG. 3. - Length frequency distribution (bars) of females (a) and males (b) of Palaemon elegans with seasonal von Bertalanffy growth curves (lines) superimposed. The estimated seasonal von Bertalanffy growth parameters were $\mathrm{L}_{\infty}(\mathrm{mm})=41.083, \mathrm{~K}\left(\right.$ year $\left.^{-1}\right)$ $=1.654, \mathrm{t}_{0}$ (year) $=-0.600, \mathrm{WP}=0.172$, and $\mathrm{C}=0.586$ for males and $\mathrm{L}_{\infty}(\mathrm{mm})=47.768, \mathrm{~K}\left(\right.$ year $\left.^{-1}\right)=1.115, \mathrm{t}_{0}($ year $)=-0.990, \mathrm{WP}=$ 0.548 , and $\mathrm{C}=0.904$ for females.

$3 \mathrm{ab})$. Seasonal oscillations in growth for females (C $=0.904)$ were larger than for males $(C=0.586)$. The slowest growth rate was estimated to be in June for females (WP $=0.548)$ and in February $(\mathrm{WP}=0.172$ ) for males (Fig. 4). Growth performance indices $\left(\Phi^{\prime}\right)$ derived from seasonal VBG parameters were relatively similar between females (3.41) and males (3.45) (Table 1). Maximum life span was estimated as 15 months for males and 21 months for females.

The spawning period of female $P$. elegans was similar in both years. Ripe ovaries were observed between February and September (Fig. 5a). Despite the decreasing water temperatures, development 


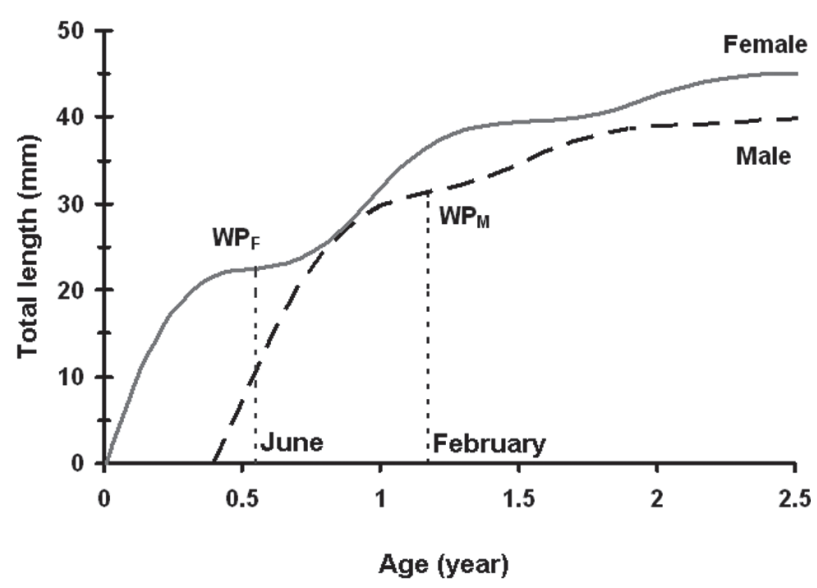

FIG. 4. - Winter points in the seasonal von Bertalanffy growth curves for females $\left(\mathrm{WP}_{\mathrm{F}}\right)$ and males $\left(\mathrm{WP}_{\mathrm{M}}\right)$ of Palaemon elegans.

of the ovaries started in February, which indicates that ovary development was probably stimulated by the photoperiod rather than water temperature. The spawning period of P. elegans was between March and September (Fig. 5b). Embryo development started with rising water temperatures in March and peaked with the highest water temperature in June. Similarly, ovigerous females with eyed eggs appeared in the population in March and peaked in June. The minimum length of an ovigerous female was $32 \mathrm{~mm}$ TL. Juvenile recruitment to the benthic population occurred at the end of summer and autumn (Fig. 2).

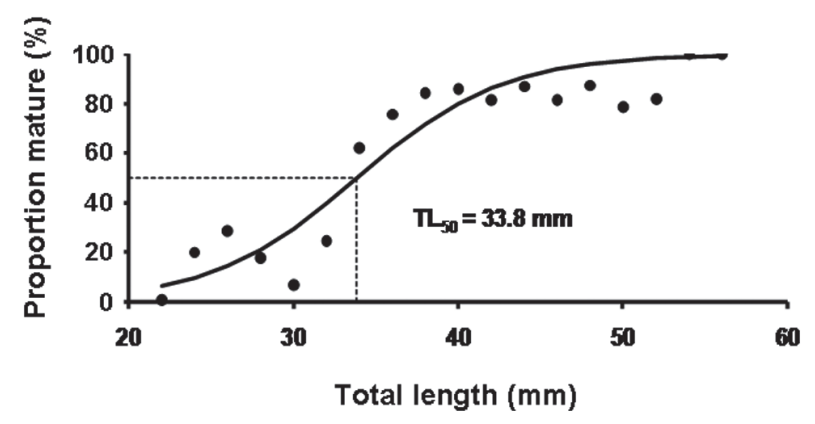

FIG. 6. - Logistic function fitting the proportion of mature Palaemon elegans females to total length (mm). $\mathrm{TL}_{50}$ corresponding to $50 \%$ of mature females.

The relationship between total length and proportion of mature females was calculated as:

$$
P=\frac{1}{1+e^{7.6307-0.2256^{*} T L}} \quad\left(\mathrm{R}^{2}=0.88, P<0.001\right) .
$$

From this, the estimated size for $50 \%$ sexual maturity for females was $33.8 \mathrm{~mm}$ TL (Fig. 6).

\section{DISCUSSION}

A seasonal growth pattern is very common in decapod crustaceans and does not only differ between species but also between sexes within a species. Guerao et al. (1994) found that females of P. xiphias exhibited a more pronounced seasonal oscillation
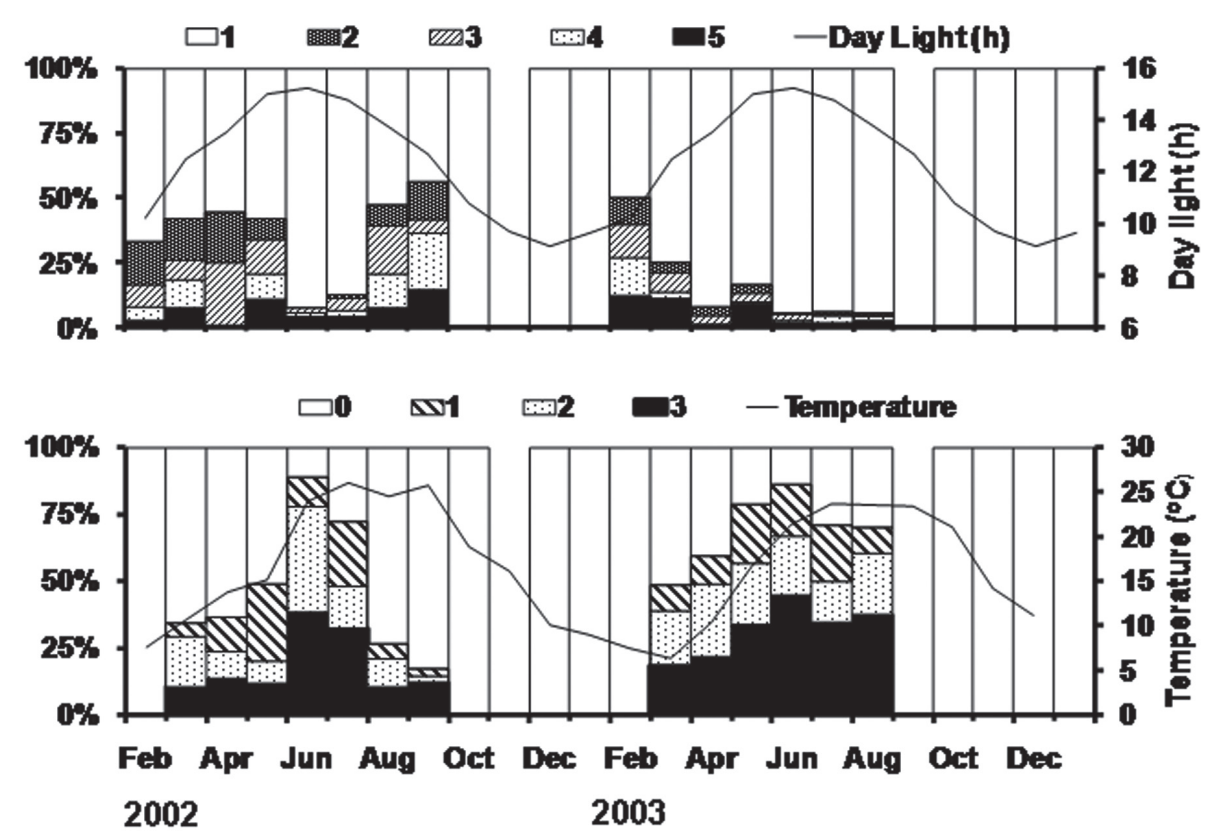

FIG. 5. - (a) Monthly proportion of ovarian maturity stages in Palaemon elegans females and daylight hours. (b) Monthly proportion of different embryonic stages in ovigerous $P$. elegans females and water temperature $\left({ }^{\circ} \mathrm{C}\right)$. 
than males. However, in P. gravieri, males had a higher seasonal oscillation rate $(\mathrm{C})$ than females in the coastal region of Namhae, Korea (Kim, 2005). Our results showed that seasonal growth oscillation of $P$. elegans was more pronounced in females. Webster (1982) found that during egg development the moult cycle of ovigerous females of $P$. elegans was prolonged. Females carrying eggs in their pleopods cannot moult and therefore their growth in the spawning season slows down; thus, seasonal growth oscillation is more pronounced (Oh et al., 2002). Besides this anecdysis period, energy allocation to reproduction may also slow down the growth of the female $P$. elegans population during the spawning season. Forster (1951) claimed that there was no evident seasonal growth pattern and growth continued throughout the year for the female $P$. elegans population in Plymouth, United Kingdom. He concluded that this continuous growth of females was due to the water temperature not fluctuating over the year as much as in Sweden where P. elegans females exhibited a seasonal growth pattern (Berglund, 1980, 1981). However, in the Black Sea, the surface water temperature fluctuates by about $19^{\circ} \mathrm{C}$ annually, and consequently $P$. elegans in this area has a seasonal growth pattern.

The period of slowest growth for females corresponded to the time when the highest proportion of ovigerous females was observed (i.e. June). The slowest growth period for males, however, was estimated to be February, which is the period with a relatively low water temperature. Since the growth rate of shrimps depends on the duration of the intermoult period, the slow growth of $P$. elegans males in winter may be the result of the extended intermoult period due to low water temperatures (Webster, 1982).

Seasonal VBG analyses showed that $\mathrm{L}_{\infty}$ was higher and $\mathrm{K}$ was lower in the female rock pool prawns. This resulted in similar growth performance indices between sexes, despite the differences in VBG parameters between males and females. Growth differences among shrimp populations have been attributed mainly to latitudinal variations (Guerao et al., 1994; Guerao and Ribera, 1995). However, since there is no information on either seasonal or nonseasonal VBG parameters for P. elegans, we were unable to compare our findings with other studies.

The growth performance index $\left(\Phi^{\prime}\right)$ can be used for averaging growth parameters obtained from the VBG equation of a particular species (Sparre and
Venema, 1992) and is a useful tool for comparing growth under a variety of environmental conditions (Pauly, 1991). The only study of species of the Palaemon genus at a similar latitude $\left(42^{\circ} \mathrm{N}\right)$ to the one in this study was conducted by Figueras (1986) on the Spanish Atlantic coast. From the VBG parameters provided by Figueras (1986) the $\Phi^{\prime}$ of $P$. adspersus was 3.70 for females and 3.52 for males, and the $\Phi^{\prime}$ of $P$. serratus was 3.96 for females and 3.84 for males. Compared to its congeners, the $\Phi^{\prime}$ values of $P$. elegans were lower for both females (3.41) and males (3.45). The growth performances of the Palaemon genus may not only be affected by latitude but also by other biotic (e.g. prey availability, predators, genetic variation) and abiotic factors (e.g. salinity, habitat structure).

The spawning period of $P$. elegans lasted for at least seven months in the Black Sea population and recruitment to the benthic population started at the end of summer. Similarly, ovigerous females of $P$. elegans were observed between April and September on the Mediterranean coast of the Valencia Gulf (Sanz, 1987). This spawning period was much shorter (about three months) in higher latitudes, Swedish west coast (Berglund, 1984), which suggests that the length of the spawning period of $P$. elegans is mainly determined by water temperature. In the Black Sea population, ovary development started much earlier than when the water temperature began to rise; it started when the photoperiod started to increase. These results support Webster (1982) who claimed that oogenesis of $P$. elegans is controlled primarily by photoperiod rather than by water temperature. An increase in temperature promoted the embryo development of $P$. elegans and the peak of the embryo development corresponded to the highest water temperature, which was in June. Similar findings of a relationship between temperature and embryo development were reported for $P$. gravieri from warm-temperate waters of southern Korea (Kim and Hong, 2004). However, the reproduction cycle of crustaceans is also affected by food conditions (Sastry, 1983).

Juveniles of $P$. elegans were found in the benthic population in early June on the Mediterranean coast of the Valencia Gulf (Sanz, 1987). In our study, juveniles appeared in the sampling gear in August. Sanz (1987) was able to sample individuals smaller than $10 \mathrm{~mm}$ TL with a sampling gear of $2 \mathrm{~mm}$ mesh size, whereas the smallest individual captured in our sampling was $14 \mathrm{~mm}$ TL. Thus, recruitment of $P$. 
elegans juveniles to the benthic population probably occurred earlier in the Black Sea than determined in this study.

The time taken to reach the onset of sexual maturity is increased by decreasing water temperatures (Hartnoll, 2001). The size at sexual maturity $\left(\mathrm{TL}_{50}\right)$ was estimated as $33.8 \mathrm{~mm}$ TL for $P$. elegans in this study. In other Palaemon species that are larger in size than $P$. elegans, the $\mathrm{TL}_{50}$ was estimated as $55.2 \mathrm{~mm} \mathrm{TL}$ for $P$. xiphias and as $54.3 \mathrm{~mm}$ TL for $P$. adspersus, in Alfacs Bay (Guerao et al., 1992; Guerao et al., 1994). In $P$. pacificus, sexual maturity was attained at 41.7 mm TL (Emmerson, 1985). In addition, geographic variations may also affect the size at sexual maturity within a species (Oh and Hartnoll, 2004).

In conclusion, seasonal growth was more pronounced in females, probably due to the long spawning period which extended the intermoult period and therefore caused individuals to grow more slowly. In males, growth was dictated by water temperature rather than reproduction activity. The reproduction period of $P$. elegans in the Black Sea population was longer than that of the population on the Swedish coast (Berglund, 1984). Ovarian development was most probably initiated by photoperiod, whereas embryo development was accelerated with increasing water temperatures.

\section{ACKNOWLEDGMENTS}

We thank Ismail Karakan, Suleyman Ozdemir, Cetin Sumer, and E. Sanver Celik for their help in the field work and two anonymous referees for their suggestions and criticism that clearly improved an earlier version of this manuscript. We would also like to thank Levent Bat who provided the water temperatures of the study area and was the leader of the project "Orta Karadeniz'de temel pelajik ekosistem parametrelerinin izlenmesi" with project number DPT 2002 KI20500 and TAP-S013.

\section{REFERENCES}

Baden, S.P. and L. Pihl. - 1984. Abundance, biomass and production of mobile epibenthic fauna in Zostera marina (L.) meadows, western Sweden. Ophelia, 23: 65-90.

Berglund, A. - 1980. Niche differentiation between two littoral prawns in Gullmar Fjord, Sweden: Palaemon adspersus and $P$. squilla. Holarctic Ecol., 3: 111-115.

Berglund, A. - 1981. Sex dimorphism and skewed sex-ratios in the prawn species Palaemon adspersus and Palaemon squilla. Oikos, 36: 158-162.
Berglund, A. - 1982. Coexistence, size overlap and population regulation in tidal vs. non-tidal Palaemon prawns. Oecologia, 54: 1-7.

Berglund, A. - 1984. Reproductive adaptations in two Palaemon prawn species with differing habitat requirements. Mar. Ecol. Prog. Ser., 17: 77-83.

Berglund, A. - 1985. Different reproductive success at low salinity determines the estuarine distribution of two palaemon prawn species. Holarctic Ecol., 8: 49-52.

Berglund, A. and U. Lagercrantz. - 1983. Genetic differentiation in populations of two Palaemon prawn species at the Atlantic east coast: does gene flow prevent local adaptation? Mar. Biol., 77: 49-57.

Bilgin, S. and O. Samsun. - 2006. Fecundity and egg size of three shrimp species, Crangon crangon, Palaemon adspersus, and Palaemon elegans (Crustacea: Decapoda: Caridea), off Sinop Peninsula (Turkey) in the Black Sea. Turk. J. Zool., 30: 413-421.

Emmerson, W.D. - 1985. Seasonal abundance, growth and production of Palaemon pacificus (Stimpson) in eastern cape tidal pools. S. Afr. J. Zool., 20: 221-231.

Evans, S.R., M. Finnie and A. Manica. - 2007. Shoaling preferences in decapod crustacea. Anim. Behav., 74: 1691-1696.

Figueras, A.J. - 1986. Crecimiento de Palaemon adspersus (Rathke, 1837) y P. serratus (Pennant, 1777) (Decapoda: Natantia) en la ría de Vigo (SO de Espana). Inv. Pesq., 50: 117-126.

Forster, G.R. - 1951. The biology of the common prawn Leander serratus Pennant. J. Mar. Biol. Assoc. U.K., 30: 333-359.

Guerao, G., J. Pérez-Baquera and C. Ribera. - 1994. Growth and reproductive biology of Palaemon xiphias Risso, 1816 (Decapoda, Caridea, Palaemonidae). J. Crustac. Biol., 14: 280-288.

Guerao, G. and C. Ribera. - 1995. Growth and reproductive ecology of Palaemon adspersus (Decapoda, Palaemonidae) in the western Mediterranean. Ophelia, 43: 205-213.

Guerao, G., C. Ribera and F. Castelló. - 1992. Biología de la reproducción de Palaemon adspersus Rathke, 1837 (Crustacea: Decapoda: Caridea) en la bahía de Els Alfacs (delta del Ebro). Bol. Soc. Port. Entomol., 1 (suppl. 3): 171-180.

Hartnoll, R.G. - 2001. Growth in Crustacea - twenty years on. Hydrobiologia, 449: 111-122.

Hoenig, J.M. and R.C. Hanumara. - 1982. A statistical study of a seasonal growth model for fishes. Tech. Report. Depart. Computer Science and Statistic, Univ. Rhode Island, Narragansett, $1-126$.

Janas, U. and J.I. Spicer. - 2008. Does the effect of low temperature on osmoregulation by the prawn Palaemon elegans Rathke, 1837 explain winter migration offshore? Mar. Biol., 153: 937-943.

Janas, U., T. Zanzycki and P. Kozik. - 2004. Palaemon elegans - a new component of the Gulf of Gdansk macrofauna. Oceanologia, 46: 143-146.

Kim, S. - 2005. Population structure, growth, mortality, and size at sexual maturity of Palaemon gravieri (Decapoda: Caridea: Palaemonidae). J. Crustac. Biol., 25: 226-232.

Kim, S. and S. Hong. - 2004. Reproductive biology of Palaemon gravieri (Decapoda: Caridea: Palaemonidae). J. Crustac. Biol., 24: 121-130.

Kirkwood, G.P., R. Aukland and S.J. Zara. - 2001. Length frequency distribution analysis (LFDA), version 5.0. MRAG Ltd, London, UK.

Lapińska, E. and A. Szaniawska. - 2006. Environmental preferences of Crangon crangon (Linnaeus, 1758), Palaemon adspersus Rathke, 1837, and Palaemon elegans Rathke, 1837 in the littoral zone of the Gulf of Gdańsk. Crustaceana, 79: 649-662.

Morris, S. and A.C. Taylor. - 1985. Oxygen consumption by Palaemon elegans (Rathke) in response to temperature change: a determinant of distribution. Exp. Biol., 44: 255-268.

Oh, C.W. and R.G. Hartnoll. - 2004. Reproductive biology of the common shrimp Crangon crangon (Decapoda : Crangonidae) in the central Irish Sea. Mar. Biol., 144: 303-316.

Oh, C.W., R.G. Hartnoll and R.D.M. Nash. - 1999. Population dynamics of the common shrimp, Crangon crangon (L.), in Port Erin Bay, Isle of Man, Irish Sea. ICES J. Mar. Sci., 56: 718-733.

Oh, C.W., H.L. Suh, K.Y. Park, C.W. Ma and H.S. Lim. - 2002. Growth and reproductive biology of the freshwater shrimp Exo-palaemon modestus (Decapoda: Palaemonidae) in a lake of 
Korea. J. Crustac. Biol., 22: 357-366.

Pauly, D. - 1991. Growth performance in fishes: rigorous description of patterns as a basis for understanding causal mechanisms. Aquabyte, 4: 3-6.

Pauly, D. and N. David. - 1981. ELEFAN-I, A basic program for the objective extraction of growth-parameters from length-frequency data. Meeresforschung-Rep. Mar. Res., 28: 205-211.

Pauly, D. and J.L. Munro. - 1984. Once more on the comparison of growth in fish and invertebrates. ICLARM Fishbyte, 2: 21.

Sanz, A. - 1987. Biología de Palaemon elegans Rathke, 1837 (Natantia: Palaemonidae) en las costas del Mediterráneo Occidental. Inv. Pesq., 51(Supl.1): 177-187.

Sastry, A.N. - 1983. Ecological aspects of reproduction. In: F.B. Vernberg and W.B. Vernberg (eds.), The biology of crustacea, pp. 179-270. Academic Press, NewYork.

Schaffmeister, B.E., J.G. Hiddink and W.J. Wolff. - 2006. Habitat use of shrimps in the intertidal and shallow subtidal seagrass beds of the tropical Banc d'Arguin, Mauritania. J. Sea Res., 55: 230-243.

Sparre, P. and S.C. Venema. - 1992. Introduction to tropical fish stock assessment. Part 1. Manual. FAO Fish. Tech. Pap., 306: 376.

Taylor, C.C. - 1958. Cod growth and temperature. J. Cons. Int. Explor. Mer, 23: 366-370.

Tuck, I.D., C.J. Chapman and R.J.A. Atkinson. - 1997. Population biology of the Norway lobster, Nephrops norvegicus (L) in the Firth of Clyde, Scotland - I: Growth and density. ICES J. Mar. Sci., 54: 125-135.

Udekem d'Acoz, C.d. - 1999. Inventaire et distribution des crustacés décapodes de l'Atlantique nord-oriental, de la Mediterranée et des eaux continentales adjacentes au nord de $25^{\circ} \mathrm{N}$. Service Patrimoine Naturel, Muséum National d'Histoire Naturelle, Paris.

Webster, S.G. - 1982. Seasonal anecdysis and moulting synchrony in field populations of Palaemon elegans (Rathke) Estuar. Coast. Shelf Sci., 15: 85-94.

Scient. ed.: F. Sardà.

Received May 13, 2008. Accepted September 2, 2008.

Published online March 2, 2009. 